NBER WORKING PAPER SERIES

\title{
UNDERSTANDING CORPORATE GOVERNANCE THROUGH LEARNING MODELS OF MANAGERIAL COMPETENCE
}

\author{
Benjamin E. Hermalin \\ Michael S. Weisbach \\ Working Paper 20028 \\ http://www.nber.org/papers/w20028
NATIONAL BUREAU OF ECONOMIC RESEARCH
1050 Massachusetts Avenue
Cambridge, MA 02138 \\ April 2014
}

The authors thank Jongha Lim, Berk Sensoy, Yihui Pan, and Tracy Wang for helpful comments on an earlier draft, and Shan Ge for excellent research assistance. Hermalin gratefully acknowledges the financial support of the Thomas \& Alison Schneider Distinguished Professorship in Finance and the hospitality of Nuffield College, Oxford. The views expressed herein are those of the authors and do not necessarily reflect the views of the National Bureau of Economic Research.

NBER working papers are circulated for discussion and comment purposes. They have not been peerreviewed or been subject to the review by the NBER Board of Directors that accompanies official NBER publications.

(C) 2014 by Benjamin E. Hermalin and Michael S. Weisbach. All rights reserved. Short sections of text, not to exceed two paragraphs, may be quoted without explicit permission provided that full credit, including (C) notice, is given to the source. 
Understanding Corporate Governance Through Learning Models of Managerial Competence Benjamin E. Hermalin and Michael S. Weisbach

NBER Working Paper No. 20028

April 2014

JEL No. D81,D83,G34,M12

\begin{abstract}
$\underline{\text { ABSTRACT }}$
A manager's shareholders, board of directors, and potential future employers are continually assessing his ability. A rich literature has documented that this insight has profound implications for corporate governance because assessment generates incentives (good and bad), introduces assorted risks, and affects the various battles that rage among the relevant actors for corporate control. Consequently, assessment (or learning) is a key perspective from which to study, evaluate, and possibly even regulate corporate governance. Moreover, because learning is a behavior notoriously subject to systematic biases, this perspective is a natural avenue through which to introduce behavioral and psychological insights into the study of corporate governance.
\end{abstract}

Benjamin E. Hermalin

Walter Haas School of Business

545 Student Services Building, \#1900

University of California

Berkeley, CA 94720-0001

hermalin@haas.berkeley.edu

Michael S. Weisbach

Department of Finance

Fisher College of Business

Ohio State University

2100 Neil Ave.

Columbus, OH 43210

and NBER

weisbach.2@osu.edu 


\section{Introduction}

Within economics, corporate governance has long been viewed through the lens of agency: the fear that a firm's managers are inclined to behave at odds with the desires of its principals (typically, the firm's shareholders). ${ }^{1}$ Yet, without minimizing the importance of agency problems, there is another key aspect to governance that has received much less attention, namely the way in which managers are assessed with respect to their intrinsic ability, competency, and match with their employer, and the effects such assessments have on the behavior of the relevant actors.

Making inferences about attributes, such as ability, from various correlates, such as firm profits, might, at first, seem like a relatively straightforward, and thus unexciting, statistical exercise. However, as has long been known in the physical sciences, the act of observation can directly affect the phenomenon being observed. As recognized initially by Fama (1980) and Holmstrom (1982), this insight has implications for incentive provision and corporate governance. $^{2}$ Moreover, unlike a sub-atomic particle or an animal in the wild, a manager understands the consequences of being observed. In particular, because the outcome of an assessment is unknown in advance, the act of observation exposes the manager to risk-for which he or she will demand compensation —with the amount of risk and, thus, compensation being dependent on the assessment protocol. Furthermore, also unlike a particle or an animal, a manager is a strategic player, who can, therefore, be expected to try to influence how he or she is

\footnotetext{
${ }^{1}$ Smith (1776, p. 700): "The directors of [joint stock] companies, however, being the managers rather of other people's money than of their own, it cannot well be expected, that they should watch over it with the same anxious vigilance [as owners] ... Negligence and profusion, therefore, must always prevail, more of less, in the management of the affairs of such a company." In the modern era, there was a revived interest in agency problems and their relation to governance led by Berle and Means (1932), Williamson (1963), and Jensen and Meckling (1976), among others. See Becht et al. (2003) and Hermalin (2013) for recent surveys of the relevant literature.

${ }^{2}$ Holmstrom's paper was originally published in 1982, in a hard to find festschrift for Lars Wahlbeck. In the prePDF 1980s, a photocopy of the working-paper version of the paper was a treasured belonging of students and scholars interested in contract theory and governance. In 1999, the Review of Economic Studies wisely reprinted the paper (Holmstrom, 1999).
} 
observed and by whom. In short, assessment-learning-profoundly affects corporate governance by generating incentives (some good, some bad); by creating a tradeoff between the accuracy of the assessment and the risk that imposes on the manager; and by creating an impetus for the manager to try to affect by whom he is observed (and governed).

The way in which the relevant parties learn about managerial ability can explain a number of factors related to firms' governance. First, the managerial labor market's assessment of a manager's ability can provide him incentives to perform well, because such assessment affects his future wages. However, such incentives are unlikely to be optimal, often being weaker than ideal, but in some instances being too strong. Worse, they can potentially have perverse effects, such as distorting managers' investment decisions. Second, assessment is a critical part of the process by which managers are chosen and fired. Consequently, management turnover is naturally studied through a learning framework. Third, what will be learned is unknown ex ante; hence, things that are functions of what is learned, such as future compensation and job retention, are necessarily uncertain ex ante, which means learning and assessment expose managers to risk. Exposure to such risk will affect their compensation demands, as well as their behavior more generally. Fourth, a manager judged to be better than average becomes a "rare commodity," which gives him or her bargaining power. This too affects compensation; but it also puts the manager in position to bargain for more control over the board of directors, leading to problems of entrenchment. Finally, learning about the ability of a firm's top management will cause a rational stock market to update its assessment of its future profits; hence, systematic relationships should exist between learning and stock return volatility. In this article, we draw from the theoretical and empirical literatures to elaborate these points, and argue that they are of first-order importance for both normative and positive analyses of governance. 
We also note that the effects above could be even more important if the assessors are "bad Bayesians" and fall foul to any of a number of well-documented biases (e.g., underweighting base rates, attribution bias, and so forth). Underweighting base rates, for instance, means that observers overweight a manager's current performance relative to his or her past record, which makes their responses to current performance more volatile than a rationalactor model might predict. Or, for instance, attribution bias means that observers tend to place too much importance on managers' roles in affecting success or failure, which makes these observers overly sensitive to what they are learning. In short, as we discuss at the end of the paper, an important way in which behavioral insights could matter for corporate governance is through their implications for how managers' abilities are assessed. Further, while behavioral factors can sometimes mute the insights from standard agency theory (e.g., intrinsic motivations lessening the importance of extrinsic incentives), behavioral biases, in particular those that make people bad Bayesians, will tend to amplify the consequences of learning (e.g., making actors "learn too much").

\section{The Good, the Bad, and the Ugly}

Fama (1980) makes the following argument: given a competitive market for managerial talent, the more able a manager appears, the greater will be the compensation she can command. Ability is inferred from performance; hence, the more successful is the firm one currently manages, the greater will be one's future compensation. ${ }^{3}$ Performance is not, though, only a function of innate ability: it can also depend on the actions the manager takes. Consequently, Fama argues, because

\footnotetext{
${ }^{3}$ This is true even if the manager stays with her current employer: the current employer will need to increase the manager's compensation in response to the outside offers her good performance elicits.
} 
of their effect on the market's inference about her ability and, thus, on her compensation, the manager has incentives to take actions that will cause her firm to perform well.

It is worth making three points about these good incentives induced by assessment. First, as Holmstrom (1982) shows, such incentives are generically sub-optimal: they can be weaker than ideal (induce less than first-best actions) or stronger than ideal (induce greater than first-best actions), but will, generically, fail to be just right. Second, as Fama acknowledges and Holmstrom demonstrates formally, these incentives tend not be constant over the course of the manager's career: the more of a known entity she becomes, the less influence any one period's performance will have on estimates of her ability, and, thus, the less powerful are her incentives to take actions the shareholders desire. Third, there is an important game-theoretic subtlety to note: although the manager pursues actions to affect the market's assessment of her ability, the actors in that market anticipate her incentive to do so and, thus, "subtract" the actions they expect her to take from realized performance before forming their estimate of her ability. In other words, in equilibrium, no one is fooled. One might, therefore, ask why the manager tries to influence the market's estimate through her choice of actions if the market will see through that? The answer is the market subtracts the actions it expects her to take-it does not see what she actually chooses to do-so if she chose not to take those expected actions, then her performance would be worse and the market would subtract its expectation from that worse performance, so her inferred ability would be correspondingly low. In essence, the manager is like the Red Queen in Lewis Carroll's Through the Looking Glass: she must run as fast as possible just to stay still.

A bit of formalism will help flesh out these ideas. Suppose the manager's ability, $\alpha$, is drawn from a normal distribution with known mean and variance. ${ }^{4}$ Suppose the value she

\footnotetext{
${ }^{4}$ The literature has used the normal distribution because it has good properties for studying learning: updating rules are straightforward and all posterior distributions are also normal.
} 
generates in a given period is the sum of her effort, $e$, and $x$, where $x$ is a normally distributed random variable with a mean equal to the manager's ability and a known variance. Suppose the manager's per-period utility is $w-c(e)$, where $w$ is her compensation and $c: \mathbb{R}_{+} \rightarrow \mathbb{R}_{+}$her costof-effort function. ${ }^{5}$ Suppose that $w$ is set each period by a competitive market for the manager; in particular, it will equal the expected value she will produce in equilibrium. ${ }^{6}$ Consequently, managerial effort in a given period does not affect her compensation in that period, from which it follows that she has no incentive to supply any effort in the last period of her career-consistent with the observation that reputational incentives "die out" over the course of a career.

Consider a manager with a two-period career. As just noted, in the second (last) period, she will supply no effort; hence, her second-period compensation will be the expected value of $x$, which in turn is the posterior estimate of her ability, $\hat{\alpha}$ (i.e., the estimate following the first period). It can be shown (see Holmstrom, 1982, for details) that

$$
\hat{\alpha}=\frac{\eta}{\eta+\rho}\left(x+e-e^{E}\right)+\frac{\rho}{\eta+\rho} \alpha_{0},
$$

where $1 / \eta$ is the variance of $x, 1 / \rho$ is the variance of $\alpha, e^{E}$ is the effort that others anticipate the manager will expend (in equilibrium, they anticipate correctly; this is the Red Queen effect), and $\alpha_{0}$ is the prior estimate of ability (in this case, the mean of ability). In the first period, the

\footnotetext{
5 In what follows, it is to be understood that $c(\cdot)$ satisfies the "standard" assumptions that ensure solutions exist to the optimization programs to be considered, that these solutions are interior, and that they vary continuously with respect to the exogenous parameters.

${ }^{6}$ Note there is a subtle assumption that compensation is based on the value the manager is expected to generate, not the value she does. Such an assumption can be justified in a number of ways (see, e.g., Holmstrom, 1982). The principal reason to make this assumption is in order to contrast reputational incentives with formal incentives.

${ }^{7}$ The multiplicative inverse of the variance $($ e.g., $\eta)$ is known in the literature as the precision of the distribution.
} 
manager will choose $e$ to maximize the expectation of $\hat{\alpha}-c(e){ }^{8}$ Observe her marginal return to effort is

$$
\frac{\eta}{\eta+\rho}<1
$$

Given that the social marginal return is 1 , it follows that her incentives are too weak: she will supply less than the socially optimal level of effort. This conclusion does not necessarily carry forward to a more-than-two-periods model. While it applies to the penultimate period, the fact that effort in earlier periods influences compensation in all future periods means that, early in her career, the manager's incentives could exceed the social optimal. What is general, though, is that they will not generically match the social optimal.

The discussion to this point shows that while reputational concerns are unlikely to create perfect incentives, they can create positive incentives. Unhappily, they can also distort incentives. To see how, suppose now that what the manager does is decide whether or not to pursue a project; that is, there is no effort (no $e$ nor $e^{E}$ ). Whether she has a project to pursue is uncertain and her private information. If she undertakes a project, it pays off $x$. Suppose the prior estimate of her ability, $\alpha_{0}$, is positive, so the project has a positive expected value. As before, her second-period compensation will be the posterior estimate of her ability, $\hat{\alpha}$. The posterior estimate, $\hat{\alpha}$, is given by expression (1) if a project is undertaken, but if no project is pursued it equals the prior estimate, $\alpha_{0}$. Finally, suppose, now, the manager is risk averse in future income. It follows from (1) that undertaking the project exposes the manager to risk without affecting her expected compensation (the expectation of (1) with $e \equiv e^{E} \equiv 0$ is $\alpha_{0}$ ). Given her risk aversion, it follows she will never undertake a project should she have one. In

\footnotetext{
${ }^{8}$ For convenience, we ignore discounting (i.e., the fact that the cost is borne today, but the benefit realized in the future).
} 
other words, as Holmstrom (1982) originally showed, career concerns can create the wrong incentives when it comes to undertaking (or not) risky projects. ${ }^{9}$

Matters can be yet more ugly. Suppose that $e$ now represents efforts that boost short-term (current-period) profits, but at the expense of future profits; moreover, assume the net present value of the firm would be maximized by $e=0$. The managerial cost function, $c(\cdot)$, can be seen as capturing how the manager herself judges the costs of what is, now, a myopic action. In terms of expression (1) and the analysis that follows, this has no direct effect; that is, the manager still has incentives to choose $e>0$. Given that is destructive of long-run firm value, it follows that career concerns can be harmful to the firm; in particular, they can lead to myopic decision making: a point developed and detailed in Stein (1989).

Given such ugliness, one might ask why matters are not simply resolved contractually? It is true that if complete contracting among all relevant players were feasible and unrestricted, career concerns would be unlikely to matter (e.g., all income risk could essentially be insured away). But in the real world, the relevant parties cannot fully commit to how they will use the information they learn. Because slavery is illegal and agreements among employers not to poach workers from each other violate antitrust law (even in Silicon Valley), it is impossible to insulate managers from worrying about potential employers. Other real-world frictions and restrictions likewise make it impossible to give real-world executives "no-dismissal" guarantees or promise

\footnotetext{
${ }^{9}$ Hermalin (1993) shows that if the manager must pursue some project, but projects vary in terms of risk and the risk $(i . e ., 1 / \eta)$ is observable, then the manager can have incentives to pursue the riskiest projects, regardless of expected payoff: the greater is $1 / \eta$, the smaller is $\eta$. From (1), this means more weight is being put on the nonstochastic element and less on the stochastic element; that is, the riskier is the project chosen, the less the risk to the manager's compensation. Hence, career concerns can lead both to excess caution (eschewing projects), as in Holmstrom (1982) and Holmstrom and Ricart i Costa (1986), or to taking on excessive risk, as in Hermalin (1993). See the last for more on this issue. Other papers that explore the relation between project choice and career concerns include Scharfstein and Stein (1990), Hirshleifer and Thakor (1992), Milbourn, Shockley, and Thakor (2001). Dominguez-Martinez, Swank, and Visser (2008) provide a variant on these models in which the CEO knows his ability (in contrast to the usual assumption of the literature). Now the choice to undertake a project becomes a signal of ability, which affects a number of the conclusions (in particular, high-ability CEOs may be "over active" and boards "lenient" in responding to poor performance). See Dominguez-Martinez et al. for details.
} 
them golden parachutes worth precisely equal to what they lose if dismissed. In short, it is impossible to contract away fully the negative incentives due to career concerns.

One response to an inability to write complete formal contracts is to adjust the design of institutions as a substitute means of providing desired commitment. Certain aspects of governance, such as having management-friendly boards, can be thought of in this manner, a point we develop in detail later.

The associated empirical literature has focused on the positive incentives that career concerns generate. ${ }^{10}$ But even limiting attention to the positive, the task confronting empirical scholars is daunting. Executive compensation changes from year to year for many reasons. Moreover, not all changes reflect career concerns. In particular, actual compensation reflects not only changing market assessment of ability, but also formal contractual provisions, as well as informal relational contracting.

One industry for which it is possible to measure market-based incentives is the moneymanagement industry. Berk and Green (2004) argue that the market's assessment of a manager's ability will be reflected by the inflows to the fund; when a fund performs well, the market's assessment of the managers increases and investors correspondingly invest more (presumably, until the perceived abnormal return to managerial skill disappears). One can estimate the sensitivity of new inflows to fund performance. Since one can observe the fees charged by most funds, it is possible to estimate the additional fees a fund will earn from incremental returns, which in turn can be interpreted as the return for having a better managerial reputation. Through this process, one can, therefore, estimate the indirect, market-based, managerial incentives in the money-management industry. Moreover, these incentives are undoubtedly economically

\footnotetext{
${ }^{10}$ Two exceptions are Edmans, Fang, and Lewellen (2013) and Gopalan, Milbourn, Song, and Thakor (2014), which find evidence in support of Stein's (1989) model of managerial myopia.
} 
important given investors' responsiveness to their assessments of managerial ability and the close connection between size of fund and managerial compensation.

An issue, though, with this estimation strategy is it is impossible to know what fraction of a fund's fees go to its managers as compensation. This is especially true of funds managed by large organizations, such as large mutual funds. In contrast, private equity and hedge funds tend to be relatively small organizations, in which the general partners both manage the funds and receive most of the fees. These firms are, for this reason, ideal for measuring the effect of market-based incentives.

Chung, Sensoy, Stern, and Weisbach (2012) and Lim, Sensoy, and Weisbach (2013) perform this exercise for private equity funds and hedge funds, respectively. In each case, the authors estimate the sensitivity of inflows to performance, and calculate the present value of the expected fees that occur with an incremental return. Both private equity and hedge funds have relatively large direct-incentive compensation: $20 \%$ profit-sharing plus the additional incentives that derive from management ownership. These papers use this large direct incentive compensation as a benchmark, and also calculate the "indirect Jensen-Murphy b," the amount managers receive in future income for each additional dollar returned to investors, not including the return on the managers' own investments in the fund (see Jensen and Murphy, 1990). Table 1 shows that both indirect incentives are large even relative to the large direct incentive compensation in this industry, and also represent a substantial fraction of money returned to investors. For a typical private equity fund, Chung, Sensoy, Stern and Weisbach (2012) find that indirect incentives are nearly as large as direct incentives, while Lim, Sensoy, and Weisbach (2013) find that they are about 3.4 times as large for a typical hedge fund. 
Moreover, both papers find that the cross-sectional and time-series patterns of indirect incentives are consistent with the assessment framework. Consistent with the theory's underlying logic, which predicts that assessment effects diminish over a career, indirect incentives are much higher for younger partnerships than for older ones for both private-equity and hedge funds (see Table 1). The greater uncertainty about younger partnerships' abilities means the market's updating about their abilities is more sensitive to performance, hence so too are investment inflows and, thus, future fees.

In addition, for a given ability level, funds that rely on scalable strategies should be better able than other funds to achieve good performance utilizing fresh investments. Hence, inflows will be greater for scalable-strategy funds following good performance, ceteris paribus. The market-based incentives for managers of scalable-strategy funds are, correspondingly, stronger. Consistent with this prediction, Chung, Sensoy, Stern and Weisbach (2012) find that more scalable buyout funds are associated with higher indirect incentives than less scalable venture capital funds. Similarly, Lim, Sensoy, and Weisbach (2013) find that hedge funds that follow more scalable strategies have higher indirect incentives than otherwise identical funds that follow less scalable strategies.

Taylor (2013) estimates market-based incentives for a broad sample of CEOs drawn from a number of industries using a structural-estimation approach. He assumes that the CEO and board can enter into an implicit or reputational contract that permits the board to partially insure the CEO against the income risk that assessment imposes on him. His estimates suggest that $50 \%$ of any increase in firm value due to favorable news about the CEO is captured by the CEO, whereas the CEO enjoys nearly complete insurance against downward risk. 
These estimates suggest that market-based incentives can be substantial. In addition, the theory of market-based incentives has predictions about their intertemporal pattern. Careerconcern incentives should decline over time for two reasons: ${ }^{11}$ first, the weight given any one period's performance declines as the CEO becomes a known entity; and, second, the closer the CEO is to retirement, the less time he has to capitalize on his reputation. To offset these declining indirect incentives, Gibbons and Murphy (1992) predict that optimal compensation packages have greater direct (i.e., performance-contingent) incentive pay components for CEOs close to retirement than those far from retirement. Gibbons and Murphy (1992) test this prediction using CEO compensation data drawn from a sample of large US corporations. Their estimates indicate that the sensitivity of salary and bonus to performance is, as theory predicts, significantly greater for CEOs at the end of their careers than for CEOs in the midst of them.

However, there is undoubtedly much more to the story: other factors, related to compensation, change systematically over a CEO's tenure. In particular, a successful CEO tends to gain power vis-à-vis his board of directors, allowing him to capture greater compensation: a pattern consistent with what Gibbons and Murphy find. In addition, most performance-based CEO firings occur in the first few years of a CEO's tenure (Allgood and Farrell, 2003). To induce CEOs to accept the risk inherent in such "probation," boards could effectively make implicit promises to reward them adequately later in their career should they survive.

\footnotetext{
11 A caveat: as Holmstrom (1982) shows, if the CEO's ability is not fixed, but evolves over time according to a stochastic process, then it is possible for learning to be stationary in a way that make incentives constant (at least if the CEO is infinitely lived). Most models in the literature, however, assume the CEO's ability is fixed after it is initially drawn.
} 


\section{Risky Business}

Learning creates volatility: stock prices respond to information learned about managerial ability, so does executive compensation and employment. Further, the more uncertainty that is being resolved, the greater the volatility such learning induces.

With respect to stock returns, this idea was originally introduced by Timmermann (1993) to explain the Shiller "excess volatility puzzle." Recently, Pietro Veronesi and co-authors have explored the idea that learning introduces volatility in a number of different settings. ${ }^{12}$

A recent paper by Pan, Wang, and Weisbach (2014a) extended this idea to governance in the following way. Stock prices move in response to news (good or bad) about cash flows. This movement reflects a number of things, including how the market has revised its assessment of the CEO's ability in response to such news. As uncertainty about the CEO decreases, as it should over the course of his tenure, this component of volatility should likewise decrease. In addition, firms with CEOs of more uncertain ability will, ceteris paribus, have larger (in absolute value) stock-price reactions to news, and consequently higher stock return volatility.

Pan, Wang, and Weisbach find empirical support for that hypothesis: stock return volatility and the absolute value of stock price reactions to earnings news decline with CEO tenure in a convex manner. Moreover, the decline is greater when there is higher ex ante uncertainty about CEO ability and more transparency about the firm's prospects. Furthermore, their estimates suggest that uncertainty about CEO ability contributes substantially to return

\footnotetext{
${ }^{12}$ Using a dynamic asset-pricing model. Veronesi (2000) studies the relation between stock returns and the precision of information about economic growth. Pastor and Veronesi (2003) develop a model in which stock valuations depend on a learning process of average profitability. The model generates predictions that the market-tobook ratio should increase in uncertainty about average profitability, and decrease over time for each firm because of learning. Pastor, Taylor, and Veronesi (2009) model IPO decisions in which entrepreneurs and investors learn about the average profitability from realized profits. The IPO decision for the entrepreneur is a tradeoff between benefits from diversification and those from private control. When the expected future profitability is higher than a cutoff value, it is optimal to go public. David and Veronesi (2013) construct a model where agents learn about economic and inflation regimes by observing signals such as real fundamental growth and inflation.
} 
volatility: idiosyncratic return volatility declines by $14 \%$ and total return volatility declines by $10 \%$ over the course of a CEO's first three years in office..

Learning generates uncertainty not only for those doing the learning, but also for those being learned about. A desire to avoid such risk can distort the behavior of managers (see, e.g., the discussion of project selection in the previous section). But it can also lead those under scrutiny to demand compensation for the risk that scrutiny brings. Hence, firms can face a tradeoff between improving the quality of their assessment versus the greater compensation they must pay as a consequence of better assessment.

To explore this idea, Hermalin (2005) assumes that boards of directors vary in their diligence or independence from management. Ceteris paribus, a more diligent or independent board will be more willing to monitor the CEO. ${ }^{13}$ Hence, a CEO facing a more diligent board faces a greater risk of dismissal than if he faced a less diligent board. All else equal, he will demand compensation for bearing that greater risk, which means his compensation will be higher than if he worked for less diligent directors. In other words, there should be a positive correlation between board independence and executive compensation, a phenomenon clearly evident in time-series data. ${ }^{14}$ In addition, the CEO will be tempted to mitigate his risk by working harder. Although that may be beneficial for the firm, it cannot truly help the CEO in equilibrium (the Red Queen effect again); hence, ultimately, this extra effort reduces his utility, for which he will require offsetting compensation. Consequently, while having more diligent or independent boards might seem an unambiguously good thing, in reality it can have serious costs. In particular, a likely unintended consequence of the movement by governments and exchanges to

\footnotetext{
${ }^{13}$ It places more weight on the benefits that accrue from monitoring than its costs from engaging in that monitoring relative to a less diligent or independent board.

${ }^{14}$ See Hermalin (2005) for a detailed discussion of the associated empirical literature. Such a positive correlation is less evident in cross-sectional data. Section V of Hermalin (2005) provides details of how these results can be reconciled both with each other and with his model.
} 
push for greater board independence is the striking increase in executive compensation over the past quarter century (see Hall and Liebman, 1998; Kaplan, 2012; Kaplan and Minton, 2012; and Peters and Wagner, 2014, for related empirical work).

Another policy that has been pushed by governments and exchanges is for better transparency and improved auditing and accounting systems within firms. Although, in light of Enron, such regulations and requirements are potentially warranted, they are not free (for many reasons). ${ }^{15}$ One reason, as noted by Hermalin and Weisbach (2012), is that they increase the "scrutiny risk" to which executives are exposed. Again executives will demand-and receivecompensation for bearing this additional risk. Thus, again, there could be an unintended consequence to this public policy: it could lead to an increase in executive compensation. In addition it could have other pernicious effects: as the authors show, it could exacerbate the sort of value-destroying signal jamming identified by Stein (1989). The greater the monitoring (e.g., the better is disclosure), the greater is the agent's marginal benefit from concealing or distorting information and thus the greater the effort he will expend on these undesired activities. These efforts represent an additional cost to improved monitoring.

\section{Someone to Watch Over Me}

Given the consequences being assessed has for the CEO, it stands to reason that he would seek to affect how he is assessed. One way for him to do so is to have a say in who does the assessing. How much say he might have depends on his bargaining power, which in turn will be a function of how he is initially assessed. The higher that assessment, the greater his comparative value visà-vis any replacement, which strengthens his bargaining position with his board. He can, as

\footnotetext{
${ }^{15}$ For a discussion of some of these costs, as well as for a political-economy analysis of the principal legislative response to Enron, the Sarbanes-Oxley Act, see Romano (2005).
} 
indirectly modeled in Holmstrom (1982), use that power to increase his pay; but he will also wish to use to affect the way he will be assessed subsequently.

Hermalin and Weisbach (1998) develop a model along those lines. A CEO who survives an initial round of assessment is necessarily seen as superior to any potential replacement, which gives him bargaining power. Yet, he remains vulnerable to later dismissal if future assessments are less positive. He can partially protect himself against this risk by using his bargaining power to get directors who will be "friendlier" to him appointed to the board. Over time, CEOs, particularly those who have done well and, thus, have effectively gained control over their boards of directors, can leverage that control to obtain greater compensation, as well as greater freedom to pursue their own agendas. Ultimately, the market's scrutiny of managerial abilities can go from being a means of controlling managers, to one that allows managers to capture rents and possibly cause other problems for their firms.

The case of Michael Eisner, the long-time CEO of Disney, is illustrative in this regard. In the 1980s, Eisner was considered one of the best CEOs in the US, leading Disney to a 50\% average annual return between 1984 and 1989. Eisner was rewarded handsomely: he was always among the 40 best-paid CEOs between 1985 and 1995, according to Forbes Magazine's annual compensation survey. In addition, he was able to control the process of board nominations: among those appointed were the principal of his children's elementary school, his personal attorney, and the president of Georgetown University, to which Eisner was a major contributor. ${ }^{16}$ Eventually, he was considered by the market to be one of the most entrenched CEOs, attracting the ire of institutional investors, and was finally thrown out of office in 2005 after a shareholder

\footnotetext{
${ }^{16}$ Reveta F. Bowers, Irwin Russell, and Leo J. O'Donovan, respectively. Sources: Wall Street Journal, February 20, 1998; and The New York Times, December 20, 1998.
} 
revolt and bitter board fight. ${ }^{17}$ The point of the Hermalin and Weisbach (1998) model is that the two halves of the Eisner example are fundamentally linked: by being considered a superstar, he acquired control over the board, and then used the control to further his personal agenda.

Baker and Gompers (2003), Boone et al. (2007), and Ryan and Wiggins (2004) each provide formal tests of the idea that successful CEOs are able to bargain for less independent boards. Boone et al. find that measures of CEO bargaining power and tenure are negatively correlated with board independence. Similarly, Baker and Gompers find that, when firms go public, the amount of outsider representation on the board reflects their bargaining power relative to that of the CEO. Finally, Ryan and Wiggins find that CEO pay becomes less linked to firm performance as his control over the board increases (proxied by his tenure and the proportion of insiders).

In addition, a CEO's control over the board can have real costs: Coles, Daniel, and Naveen (2013) find evidence suggesting that boards in which the majority of directors were appointed under the current CEO ("co-opted" boards) monitor less than boards in which such directors are a minority: CEO compensation tends to be higher and performance-based turnover lower with the former than the latter. Relatedly, Pan, Wang, and Weisbach (2014b) find that firms with co-opted boards tend to make more investments, but of lower quality, than firms without co-opted boards. Moreover, unwinding that control is not without cost: via a structural model, Taylor (2010) estimates, based on their CEO-firing decisions, that boards behave as if it costs \$200 million, on average, to replace a CEO; a figure Taylor attributes to the cost of changing the incumbent CEO's strategy (i.e., undoing his entrenchment). He offers this as one reason for the low CEO-firing (forced turnover) rate in US public corporations.

\footnotetext{
17 See, e.g., the New York Times, September 26, 2005.
} 
Common to most of the literature (see, e.g., the discussion of project selection in Section 2), is that the CEO would strictly prefer that the board learn nothing about him ceteris paribus. If the board learns nothing, then its belief is the prior and, as discussed in the context of expression (1), that means the CEO is exposed to no risk. One can, though, conceive of situations in which the CEO might have conflicted preferences: if the board gains certain information, it will update its beliefs about him (thus exposing him to risk—a minus), but it will also be in a better position to advise him (a plus). If such advice is valuable to the firm, then the board may wish to commit to being "friendly"; that is, put in place strictures (e.g., fewer independent directors, directors known to be positively biased toward the CEO, etc.) that limit its reaction if it learns negative information about the CEO. This provides the CEO some assurance that he can share information with the board with limited risk of repercussions. This idea that there are, thus, tradeoffs between assessing the CEO and advising him has been explored in the "friendly boards" literature, of which two key contributions are Adams and Ferreira (2007) and Harris and Raviv (2008). ${ }^{18}$

It is also worth remembering that the monitors-the board of directors-consist of individuals who also care about how they are perceived. There is evidence that directors' reputations are affected by the success or failure of the firms they oversee; for example, Fich and Shivdasani (2007) find evidence that directors of firms that are alleged to have engaged in financial fraud pay a significant price in terms of getting and maintaining directorships in other firms. At a theoretical level, Hermalin and Weisbach (1998) note that a CEO dismissal could be good news about board quality because it signals that the directors are more prone to monitor. However, as Dow (2013) observes, CEO dismissal could also be a bad signal, insofar as it

\footnotetext{
${ }^{18}$ For a more in-depth introduction to this literature see Adams, Hermalin, and Weisbach (2010), especially Section
} 2.3. 
indicates the board is poor at assessing quality at the time of initial appointment. The fact that outsiders will draw inferences will, in turn, affect the decisions boards will make (possibly for good — they may be more vigilant about preventing financial fraud—or for bad—they may be more lenient toward the CEO to avoid looking bad for having chosen him in the first place).

\section{Altered States}

The discussion to this point has presumed that all learning is rational; that is, updating is in accord with Bayes Law. However, evidence suggests that, in reality, people tend to be poor Bayesians and are prone to cognitive biases. Three such biases seem especially relevant here: the "base-rate fallacy," the "hot-hand fallacy" and the "fundamental-attribution bias." 19 The first is a tendency to overweight the recent past and underweight base rates; that is, overweighting the signal and underweighting the prior estimate. The second, somewhat relatedly, is a tendency to forecast future success based on a recent run of success (e.g., to assume a higher probability than warranted to a basketball player's making her next shot simply because she has hit her last three). ${ }^{20}$ The third is to assign more credit (or blame) to an individual and less to her circumstances than is appropriate.

The implication of the base-rate fallacy can readily be seen from expression (1), which is a weighted average of new information and the prior (the weights are $\eta /(\eta+\rho)$ and $\rho /(\eta+\rho)$, respectively). A shift of weight to the first from the second will increase the CEO's incentives to

\footnotetext{
${ }^{19}$ Kahneman (2011) provides an excellent summary of the literature documenting ways in which human behavior departs from rationality, including these three (and other) biases.

${ }^{20}$ The "hot-hand fallacy" was originally documented by Gilovich et al. (1985). A related fallacy is the falsereversion-to-mean fallacy: the erroneous prediction, e.g., that someone who has had a run of heads is "due" to flip a tail on her next toss.
} 
affect the signal. This can be good (he works harder), bad (it distorts his investment decisions), or ugly (it reinforces his motives to pursue myopic strategies).

In one sense, the hot-hand fallacy is an extreme version of the base-rate fallacy. In the basketball context, in which the fallacy was originally observed, it turns out that a player's field goal percentage is roughly constant over time (e.g., over a season or two) and there is little to no serial correlation within a particular game. Hence, the right "model" is that each shot she takes has an independent probability $p$ of being good, so $p$ should be the probability with which one should expect her next shot to hit, even if she's enjoyed a run of success (just as one knows a fair coin will land heads with probability $1 / 2$ no matter how many heads in a row have just been tossed). The hot-hand fallacy is, in essence, the false belief that there is something to be learned when there is, in fact, nothing to learn-sufferers will assign a weight less than one to the prior (base rate) even though, here, one is the correct weight to assign.

Another way to view the hot-hand fallacy is that people are using the wrong stochastic model. Suppose that, as is standardly assumed in the literature, a CEO's ability is fixed over time. If, instead, one mistakenly believed that it followed a random walk (or other process with serial correlation), then one would believe that there is more to be learned from recent events than there truly is. In this regard, it is worth noting that Holmstrom (1982) considers an extension of the basic career-concerns model that encompasses abilities that follow a random walk. Although the resulting formulae are different in this version of the model than the one with fixed ability, the basic conclusions discussed above continue to hold—at least if abilities truly follow a random walk and this is commonly understood. What could prove interesting is to explore the deviations in beliefs, efforts, compensation, and so forth when people are subject to the hot-hand fallacy (falsely believe, e.g., ability follows a random walk). To the best of our knowledge, no 
one has extended the career-concern model to allow for the possibility that some or all observers are using an erroneous model of the underlying stochastic process.

The fundamental-attribution bias is somewhat trickier. If there is only one signal of performance, then there is no means of identifying what is attributable to the manager and what to circumstances. In some settings, though, inferences could be made about circumstances by comparing the performance of a given firm to others in the same industry. Differences in relative performance could help identify the degree to which the firm's success (or lack thereof) should be attributable to its CEO and the degree attributable to circumstances beyond his control. ${ }^{21}$ The extent to which markets appropriately adjust for circumstances beyond the CEO's control is somewhat unclear: although there is some evidence that relative performance is taken into account (Gibbons and Murphy, 1990), there is also evidence that it is not (Bertrand and Mullainathan, 2001).

Another issue is that if managers know they will be assessed in a relative way, then, consistent with the general point that the act of observation can distort incentives, such assessment could lead to suboptimal behavior. For instance, Scharfstein and Stein (1990) present a model in which relative-performance assessment yields herding in investment decisions: as with wildebeests on the Serengeti, standing out from the herd is a good way to get picked off by predators. But while herding can be good for wildebeests and CEOs, it can be quite suboptimal from the perspective of shareholders.

Despite the difficulties of identifying managerial ability from circumstances, there are reasons to suspect that markets give too much credit to managers. In the management literature, Khurana $(2002 \mathrm{a}, \mathrm{b})$ has made a compelling case that there is a misguided tendency to treat a

\footnotetext{
${ }^{21}$ Wasserman, Anand, and Nohria (2010) find evidence that who the CEO is does matter, but this effect varies considerably across industries.
} 
number of CEOs as superstars. In addition, experimental work suggests that subjects have a tendency to overweight the importance of the leader to a team's success or failure (see, in particular, Weber et al., 2001).

At the same time, one needs to ask whether cognitive biases evidenced by students playing for small stakes in psychology labs necessarily have bearing in a corporate world in which governance mistakes have the potential to destroy billions of dollars? Put slightly differently, Bayes Rule is not a secret formula and the incentives to get matters right are huge, so shouldn't boards and others overcome these biases? As noted, there are some hints in the empirical literature that the answer may nonetheless be "no," but obviously how accurately the relevant actors adjust their beliefs is an empirical question, one in need of more research. We note too that the existence of such biases, at least if they are truly critical, also matter for our assessment of past empirical studies. These distortions, for instance, potentially wreak havoc on structural estimation procedures based on the assumption that the Bayesian updating is rational.

Beyond determining the existence and magnitude of these biases in the context of governance, a number of avenues of research seem open. First, from a theoretical perspective, it is not necessarily obvious what the effect of these biases will be. For example, the base-rate fallacy causes observers to overweight current performance, which could increase a young executive's incentives relative to what they would be if observers were perfect Bayesians. On the other hand, if the past will be effectively forgotten, the long-run effects that current effort has on future compensation will be less than theory based on Bayesian updating predicts, which would reduce a young executive's incentives. Hence, one avenue of research is to determine the theoretical consequences if the relevant parties employ updating/inference rules exhibiting welldocumented biases. 
A second set of questions stem from the insight that if these biases are predictable and lead others to behave suboptimally, then ought there not be ways for one to make money off of them? That is, why can't savvy players effectively "print money" at the expense of the less savvy? One possible answer is to imagine that there is some process - to the best of our knowledge, as yet unmodeled in this context - that causes competition among the savvy players to drive the relevant institutions to an equilibrium in which they are led to act as if run by good Bayesians.

Alternatively, it might actually be profitable in some ways to have a firm's board be bad Bayesians. Consider equation (1) one more time. If all boards suffered from such a severe case of the base-rate fallacy such that $\rho=0$ for them, then any given CEO's return to effort is 1 , matching the social return; that is, in a world of biased boards, the first best attains. ${ }^{22}$ Admittedly, this is a highly incomplete analysis - and certainly one can also imagine reasons why a board of bad Bayesians is bad-but it serves to illustrate one way in which cognitive biases could be a plus.

Another way cognitive biases could be a plus is by serving as a commitment device. ${ }^{23}$ To illustrate this possibility, another well known learning-related bias is confirmation bias, the tendency to look for or overweight evidence confirming a decision and to ignore or underweight evidence contrary to it. Consider two boards, one with confirmation bias, one without. Suppose, as in Section 2, CEOs decide whether or not to pursue projects. The CEO working for the board without bias will, for the reasons detailed in Section 2, never undertake a project. The story could be different for the CEO working for the board with bias. If this board wishes to confirm

\footnotetext{
22 This is based on the assumption of no discounting. But even allowing for discounting, the base-rate fallacy would generally seem to make incentives arising from career concerns more efficient.

${ }^{23}$ The discussion that follows is somewhat related to a strain of the leadership literature that deals with delegation. See, e.g., Rotemberg and Saloner (1993, 1994, 2000), Van den Steen (2005), and Blanes i Vidal and Möller (2007).
} 
the wisdom of its selection of the CEO, it will tend to overlook or at least underweight a project failure, while noticing and overweighting a project success. Although choosing a project still exposes the CEO to risk, the magnitude of the risk-adjusted upside can exceed the magnitude of the risk-adjusted downside, which means he could wish to undertake projects. In short, the board's confirmation bias could commit it to being more lenient toward failure, which is necessary if the CEO is to be induced to pursue projects at all. Again, this is a highly incomplete analysis - and certainly one can also imagine reasons why a lenient board is bad-but it is suggestive of possible lines of future work.

In summary, there is a natural complementarity between the learning and assessment approach to governance and behavioral economics. Although, as noted, it is possible that market forces drive the relevant actors to behave as if they are good Bayesians, there are also many reasons to suspect that managerial ability is assessed in such a way that the relevant actors are updating their beliefs in a decidedly non-Bayesian manner. If so, then our understanding of the corresponding governance phenomena will be vastly enriched by incorporating the various insights arising from research on cognitive biases.

\section{Fin}

The central focus of research in corporate governance has historically been on the problems of controlling managers' actions. Without minimizing the real-world importance of such control problems, we argue that such a focus is incomplete and ignores important factors affecting corporate governance. In particular, it overlooks the crucial element of career concerns: managers care about the inferences that current and future employers draw over time about their abilities from observing their performance. 
Career concerns create powerful incentives for managers. Sometimes they are valuable, as Fama (1980) argues, but sometimes they can prove counterproductive, as Holmstrom (1982) and others demonstrate. In addition, because what others will ultimately infer about them is uncertain ex ante, managers are necessarily exposed to risk, which leads them to demand greater compensation. Further, because what is left to learn decreases over a manager's career, the corresponding uncertainty likewise decreases, which has numerous implications. Finally, how managers are assessed and by whom are endogenous decisions; decisions that are fundamentally about the design of governance structures. In short, there are a number of reasons to expect career concerns to be a major factor in corporate governance.

Of particular note is the importance of career concerns-a learning and assessment perspective more generally—for understanding the dynamics of corporate governance. Such a perspective seems essential for gaining insights into phenomena such as executive selection and turnover; the evolution of executive salaries and other forms of non-contingent compensation; changes in the balance of power between boards and CEOs; and the changes in the volatility of stock returns over time.

Although by no means comprehensive, our discussion of the extant literature nonetheless amply illustrates that this approach has already yielded considerable insights into governance. Yet it is not a spent force: we believe it remains a rich approach going forward. This is especially true for empirical work. A striking feature of the models in this literature is how well suited they are to testing: as a rule, they offer clear time-series and cross-sectional predictions. These predictions occur, in large part, because beliefs about ability are, almost by necessity, more volatile to the current performance of newcomers than of old-timers. In addition, other observables are closely correlated with factors such as the precision of the relevant prior estimate 
of ability or the precision of the signals available to the market. While some of these insights have already been explored empirically, many remain to be investigated.

One potential shortcoming of the current literature is that it has ignored the welldocumented fact that most people are "bad Bayesians"- they fail, in systematic and predictable ways, to update their beliefs in a manner consistent with Bayes Rule. As we discussed in detail above, recognition of this fact opens a number of crucial avenues of research, both empirical and theoretical. No doubt the most critical issue in this regard is determining empirically how far real-world belief formation deviates from the Bayesian ideal in the context of governance.

In sum, learning and assessment offers a complementary approach to agency theory for the study of corporate governance; in particular, it is a means to provide a unifying framework to a number of disparate phenomena in governance. Further, it is an approach amenable to empirical analysis and, indeed, a rich empirical literature has emerged that builds implicitly and explicitly on it. Finally, it offers natural ways to incorporate behavioral insights into the study of governance. 


\section{References}

Adams, Renée B., and Daniel Ferreira (2007) “A Theory of Friendly Boards,” Journal of Finance, 62(1), 217-50.

Adams, Renée B., Benjamin E. Hermalin, and Michael S. Weisbach (2010) "The Role of Boards of Directors in Corporate Governance: A Conceptual Framework and Survey," Journal of Economic Literature, 48(1), 58-107.

Allgood, Sam and Kathleen A. Farrell (2003) "The Match between the CEO and Firm," Journal of Business, 76, 317-341.

Baker, Malcolm, and Paul A. Gompers (2003) "The Determinants of Board Structure at the Initial Public Offering," Journal of Law and Economics, 46(2), 569-98.

Becht, Marco, Patrick Bolton, and Ailsa Röell (2003) "Corporate Governance and Control," in George Constantinides, Milton Harris, and René Stulz, eds., The Handbook of the Economics of Finance, Amsterdam: North-Holland.

Berk, Jonathan and Richard Green (2004) "Mutual Fund Flows and Performance in Rational Markets," Journal of Political Economy, 112, 1269-1295.

Berle, Adolph A. and Gardiner C. Means (1932) The Modern Corporation and Private Property, New York: MacMillan.

Bertrand, Marianne and and Sendhil Mullainathan (2001) "Are CEOs Rewarded for Luck? The Ones Without Principals Are,” Quarterly Journal of Economics, 116, 901-932.

Blanes i Vidal, Jordi and Marc Möller (2007) "When Should Leaders Share Information with Their Subordinates?," Journal of Economics \& Management Strategy, 16(2), 251-283.

Bolton, Patrick and Mathias Dewatripont (2005) Contract Theory, Cambridge, MA: MIT Press.

Boone, Audra L., Laura Casares Field, Jonathan M. Karpoff, and Charu G. Raheja (2007) "The Determinants of Corporate Board Size and Composition: An Empirical Analysis," Journal of Financial Economics, 85(1), 66-101.

Carroll, Lewis (1871) Through the Looking Glass, and What Alice Found There, New York: Macmillan.

Chung, Ji-Woong, Berk A. Sensoy, Lea H. Stern, and Michael S. Weisbach (2012) "Pay for Performance from Future Fund Flows: The Case of Private Equity," Review of Financial Studies, 25, 3259-3304.

Coles, Jeffrey, Naveen Daniel and Lalitha Naveen (2013) "Co-opted Boards: Costs, Benefits, Causes and Consequences," Review of Financial Studies, forthcoming.

David, Alexander, and Pietro Veronesi (2013), "What Ties Return Volatilities to Price Valuations and Fundamentals?" Journal of Political Economy, 121 (4), 682-746.

Dominguez-Martinez, Silvia, Otto H. Swank, and Bauke Visser (2008) “In Defense of Boards," Journal of Economics and Management Strategy, 17(3), 667-82. 
Dow, James (2013) "Boards, CEO Entrenchment, and the Cost of Capital," Journal of Financial Economics, 110, 680-695.

Edmans, Alex, Vivian Fang, and Katharina Lewellen (2013), "Equity Vesting and Managerial Myopia", Working Paper.

Fama, Eugene F. (1980) "Agency Problems and the Theory of the Firm," Journal of Political Economy, 88, 288-307.

Fich, Eliezer M., and Anil Shivdasani (2007) "Financial Fraud, Director Reputation, and Shareholder Wealth," Journal of Financial Economics, 86(2), 306-36.

Gibbons, Robert and Kevin J. Murphy (1990) "Relative Performance Evaluation for Chief Executive Officers," Industrial and Labor Relations Review, 43, 30S-51S.

Gibbons, Robert and Kevin J. Murphy (1992) "Optimal Incentive Contracts in the Presence of Career Concerns: Theory and Evidence," Journal of Political Economy, 100, 468-505.

Gilovich, Thomas, Amos Tversky and R. Vallone, (1985) "The Hot Hand in Basketball: On the Misperception of Random Sequences". Cognitive Psychology 3 (17): 295-314.

Gopalan, Radhakrishnan, Todd T. Milbourn, Fenghua Song, and Anjan V. Thakor (2014), "Duration of Executive Compensation," The Journal of Finance, forthcoming.

Hall, Brian J. and Jeffrey B. Liebman (1998) “Are CEOs Really Paid Like Bureaucrats?" Quarterly Journal of Economics, 113, 653-691.

Harris, Milton, and Artur Raviv (2008) “A Theory of Board Control and Size," Review of Financial Studies, 21(4), 1797-1832.

Hermalin, Benjamin E. (1993) "Managerial Preferences Concerning Risky Projects," The Journal of Law, Economics, and Organization, 9, 127-135.

Hermalin, Benjamin E. (2005) "Trends in Corporate Governance" The Journal of Finance, 60, 23512384.

Hermalin, Benjamin E. (2013) "Corporate Governance," in Robert S. Gibbons and John Roberts, eds., The Handbook of Organizational Economics, Princeton, NJ: Princeton University Press.

Hermalin, Benjamin E. and Michael S. Weisbach (1998) "Endogenously Chosen Boards of Directors and their Monitoring of the CEO," American Economic Review, 88, 96-118.

Hermalin, Benjamin E. and Michael S. Weisbach (2012) "Information Disclosure and Corporate Governance," The Journal of Finance, 67, 195-233.

Hirshleifer, David A. and Thakor, Anjan V. (1992) "Managerial Conservatism, Project Choice, and Debt," Review of Financial Studies, 5, 437-470.

Holmstrom, Bengt (1982) "Managerial Incentive Problems -- A Dynamic Perspective," in Essays in Honor of Lars Wahlbeck, Helsinki: Swedish School of Economics. 
Holmstrom, Bengt (1999) "Managerial Incentive Problems: A Dynamic Perspective," Review of Economic Studies, 66, 169-182.

Holmstrom, Bengt and Joan Ricart i Costa (1986) "Managerial Incentives and Capital Management," Quarterly Journal of Economics, 101, 835-860.

Jensen, Michael C. and William H. Meckling (1976) "Theory of the Firm: Managerial Behavior, Agency Costs, and Capital Structure," Journal of Financial Economics, 3, 305-360.

Jensen, Michael C. and Kevin J. Murphy (1990) "Performance Pay and Top Management Incentives," Journal of Political Economy, 98, 225-264.

Kahneman, Daniel (2011) Thinking, Fast and Slow, Farrar, Strauss, and Giroux: New York.

Kaplan, Steven N. (2012) "Executive Compensation and Corporate Governance in the U.S.: Perceptions, Facts and Challenges," Unpublished working paper, University of Chicago, Booth School of Business.

Kaplan, Steven N. and Bernadette A. Minton (2012) "How has CEO Turnover Changed?" International Review of Finance, 12, 57-87.

Khurana, Rakesh (2002a) "The Curse of the Superstar CEO," Harvard Business Review, 80(9), 60-65.

Khurana, Rakesh (2002b) Searching for a Corporate Savior: The Irrational Quest for Charismatic CEOs, Princeton, NJ: Princeton University Press.

Lim, Jongha, Berk A. Sensoy, and Michael S. Weisbach (2013) "Indirect Incentives of Hedge Fund Managers," Working Paper, Ohio State University.

Milbourn, Todd T., Richard L. Shockley (2001) "Managerial Career Concerns and Investments in Information," RAND Journal of Economics, 32(2), 334-351.

Pan, Yihui, Tracy Yue Wang, and Michael S. Weisbach (2014a) "Learning about CEO Ability and Stock Return Volatility," Working Paper, Ohio State University.

Pan, Yihui, Tracy Yue Wang, and Michael S. Weisbach (2014b) "CEO Investment Cycles," Working Paper, Ohio State University.

Pastor, Lubos, Lucian A. Taylor, and Pietro Veronesi (2009), "Entrepreneurial learning, the IPO decision, and the post-IPO drop in firm profitability," Review of Financial Studies, 22 (8), 3005-3046.

Pastor, Lubos, and Veronesi Pietro (2003), "Stock valuation and learning about profitability," Journal of Finance, 58 (5), 1749-1790.

Peters, Florian S. and Alexander F. Wagner (2014), "The Executive Turnover Risk Premium," The Journal of Finance, forthcoming.

Rochet, Jean-Charles (1985) "The Taxation Principle and Multi-Time Hamilton-Jacobi Equations," Journal of Mathematical Economics, 14, 113-128. 
Rotemberg, Julio J. and Garth Saloner (1993) "Leadership Style and Incentives," Management Science, 39(11), 1299-1318.

Rotemberg, Julio J. and Garth Saloner (1994) "Benefits of a Narrow Business Strategy," American Economic Review, 84(5), 1330-1349.

Rotemberg, Julio J. and Garth Saloner (2000) "Visionaries, Managers, and Strategic Direction," RAND Journal of Economics, 31, 693-716.

Romano, Roberta (2005) "The Sarbanes-Oxley Act and the Making of Quack Corporate Governance," Yale Law Journal, 114, 1521-1611.

Ryan, Harley E., Jr., and Roy A. Wiggins III (2004) "Who Is in Whose Pocket? Director Compensation, Board Independence, and Barriers to Effective Monitoring," Journal of Financial Economics, 73(3), 497524.

Smith, Adam (1776) An Inquiry into the Nature and Causes of the Wealth of Nations, London: W. Strahan and T. Cadeli, in the Strand.

Scharfstein, David S. and Stein, Jeremy C. (1990) "Herd Behavior and Investment," American Economic Review, 80 465-479.

Stein, Jeremy C. (1989) "Efficient Capital Markets, Inefficient Firms: A Model of Myopic Corporate Behavior," Quarterly Journal of Economics, 104, 655-669.

Taylor, Lucian A. (2010) "Why are CEOs Rarely Fired? Evidence from Structural Estimation," The Journal of Finance, 65 (6), 2051 - 2087.

Taylor, Lucian A. (2013) "CEO Wage Dynamics: Estimates from a Learning Model," Journal of Financial Economics, 108, 79-98.

Van den Steen, Eric (2005) “Organizational Beliefs and Managerial Vision,” Journal of Law, Economics, \& Organization, 21(1), 256-283.

Veronesi, Pietro (2000), "How does information quality affect stock returns?" Journal of Finance, 55 (2), 807-837.

Wasserman, Noam, Bharat Anand, and Nitin Nohria (2010) "When Does Leadership Matter? A Contingent Opportunities View of CEO Leadership" in Nitin Nohria and Rakesh Khurana, eds., Handbook of Leadership Theory and Practice, Boston: Harvard Business School Publishing.

Weber, Roberto A., Colin F. Camerer, Yuval Rottenstreich, and Marc Knez (2001) "The Illusion of Leadership: Misattribution of Cause in Coordination Games," Organization Science, 12(5), 582-598.

Williamson, Oliver E. (1963), "Managerial Discretion and Business Behavior," American Economic Review, 53 (5), 1032-1057. 


\section{Table 1}

\section{The ratio of indirect to direct incentives and the "Jensen-Murphy b" for different types of funds.}

The "Jensen-Murphy $b^{\prime \prime}$ (in italics) is defined here as the present value of the change of managers' revenue from indirect incentives associated with every dollar returned to the investors other than the managers. Panel A reports numbers for private equity funds from Chung, Sensoy, Stern, and Weisbach (2012), Panel B those for hedge funds from Lim, Sensoy, and Weisbach (2013). The first two rows report the averages for all the funds included in the samples. The following two rows report the numbers by fund age or fund sequence. The last two rows report the numbers by scalability of the fund. Numbers in Panel A are calculated using Tables 5 and 6 in Chung, Sensoy, Stern, and Weisbach (2012), where the maximum number of future funds the GP could potentially run is $3 . k$ is the expected fraction of future fund sizes that the GP receives as compensation. Numbers in Panel B are calculated using Table 4 in Lim, Sensoy, and Weisbach (2013), with investors' asset value based liquidation point equal to 0.8 .

\begin{tabular}{|c|c|c|c|c|}
\hline \multirow{2}{*}{$\begin{array}{c}\text { Full Sample } \\
\text { Indirect/Direct }\end{array}$} & \multicolumn{2}{|c|}{ Panel A: Private Equity } & \multicolumn{2}{|c|}{ Panel B: Hedge Fund } \\
\hline & \multicolumn{2}{|c|}{0.63} & \multicolumn{2}{|l|}{3.42} \\
\hline Jensen-Murphy b & \multicolumn{2}{|c|}{0.11} & \multicolumn{2}{|l|}{0.62} \\
\hline \multirow{2}{*}{ By Sequence/Age } & \multicolumn{2}{|c|}{ Current Fund Sequence (k=20\%) } & \multicolumn{2}{|c|}{ Fund Age (years) } \\
\hline & 1 & 3 & $0 \sim 1$ & $3 \sim 4$ \\
\hline Indirect/Direct & 0.55 & 0.32 & 7.00 & 3.51 \\
\hline Jensen-Murphy b & 0.10 & 0.06 & 0.85 & 0.56 \\
\hline By Scalability & $\begin{array}{c}\text { Buyout } \\
(\mathrm{k}=17.72 \%)\end{array}$ & $\begin{array}{c}\text { Venture } \\
(\mathrm{k}=22.84 \%)\end{array}$ & Not Capacity Constrained & $\begin{array}{c}\text { Capacity } \\
\text { Constrained }\end{array}$ \\
\hline Indirect/Direct & 1.24 & 0.48 & 3.80 & 2.81 \\
\hline Jensen-Murphy $b$ & 0.24 & 0.08 & 0.67 & 0.52 \\
\hline
\end{tabular}

